\title{
Effects of reproductive tract development and hormonal treatment on estrous synchronization in heifers
}

\author{
Jorge Alonso Peralta-Torres ${ }^{1 *}$, Jesús Ricardo Aké-López², Carlos Luna-Palomera1, \\ José Candelario Segura-Correa², Oswaldo Margarito Torres-Chablé1, Nadia Florencia Ojeda-Robertos ${ }^{1}$ \\ ${ }^{1}$ División Académica de Ciencias Agropecuarias, Universidad Juárez Autónoma de Tabasco. Carretera Villahermosa-Teapa Km. 25, R/A La \\ Huasteca $2^{a}$ Sección, CP.86280, Villahermosa, Tabasco, México. Tel. (993) 3581585, 1429151, Fax: (993) 1429150, ${ }^{2}$ Facultad de Medicina \\ Veterinaria y Zootecnia. Universidad Autónoma de Yucatán. Carretera Mérida-Xmatkuil Km. 15.5, Apdo. 4-116 Itzimná, CP 97100, Mérida, \\ Yucatán, México. Tel. (999) 942 3200; ext. 23 Fax (999) 9423205.
}

\section{A B S TR A C T}

Evaluation of the reproductive tract development (RTD) is a criterion rarely used when heifers are included in estrous synchronization programs. The objective of the present study was to determine the effect of RTD (mature and immature) and hormonal treatment (EC and $\mathrm{EB}$ ) on estrous expression rate and pregnancy rate in Bos indicus heifers under tropical conditions. RTD was evaluated with an ultrasound and classified as mature $(n=99)$ or immature $(n=101)$. Heifers received an intravaginal device (DIB ; day 0$), 2$ mg of estradiol benzoate (EB) and $250 \mu \mathrm{g}$ of cloprostenol $\left(\mathrm{PGF}_{2} \alpha\right)$. The DIB was removed on day 7 post insertion, and $250 \mu \mathrm{g}$ of $\mathrm{PGF}_{2} \alpha$ was applied and heifers were divided into two groups: One group of heifers received $0.5 \mathrm{mg}$ of estradiol cypionate (EC group), and on day 8 , a second group of heifers received $1 \mathrm{mg}$ of estradiol benzoate (EB group). Estrus was detected by visual observation, and all heifers were inseminated at a fixed-time (FTAI). Fifteen days after insemination, bulls were introduced to the treatment groups. Data were analyzed using general modeling and binary logistic regression procedures. The percentage of estrus was similar for both mature and immature heifers $(P>0.05)$, however, the heifers treated with EB had $17 \%$ animals in estrus, than the heifers that received EC $(P<0.05)$. The pregnancy rate after FTAI $(74.8 \%)$ and total pregnancy (FTAI + natural mating $=91.9 \%)$ was greater for the group of heifers with a mature reproductive tract $(\mathrm{P}<0.05)$. The hormone treatment had not effect $(P>0.05)$ on the pregnancy rate. In conclusion, the heifers with mature reproductive tracts had the highest pregnancy rate after artificial insemination and total pregnancy. Hormonal treatment did not influence the pregnancy rate.

Keywords: Bos indicus; Estradiol benzoate; Estradiol cypionate; Pregnancy rate; Tropics.

\section{INTRODUCTION}

In the bovine production systems under tropical conditions, the most common criteria for replacement of heifers are body condition score, body weight, and age of heifer (Barcellos et al., 2014; Lardner et al., 2014). Evaluation of the reproductive tract is rarely applied, probably because it requires transrectal palpation of the internal genital organs to check the development of the uterus and ovaries. However, it has been shown to be a useful tool for decision making and tends to improve the breeding success of the herd by excluding heifers that probably cannot become pregnant during their first breeding season (Holm et al., 2009; Gutierrez et al., 2014; Dickinson et al., 2019).

In this sense, the evaluation of reproductive tract development (RTD) has been used to determine the age at puberty (Monteiro et al., 2013; Holm et al., 2015; Bruinjé et al., 2019), fertility in postpartum cows (Baez et al., 2016; Holm et al., 2016) and the response to estrus synchronization (Kasimanickam et al., 2016; Kasimanickam et al., 2020). Young et al. (2011) indicated that the size of the reproductive tract at the time of artificial insemination could be related to the fertility of dairy cattle.

Moreover, a high percentage of Bos indicus and cross beef heifers in fixed-time artificial insemination (FTAI) programs have been reported to have immature reproductive tracts (Claro et al., 2010; Kasimanickam et al., 2017). This was associated with a poor pregnancy rate because of the asynchrony between estrus and ovulation (Bó and Baruselli, 2014). One option to improve the synchrony between

\footnotetext{
*Corresponding author:

Jorge Alonso Peralta-Torres, División Académica de Ciencias Agropecuarias, Universidad Juárez Autónoma de Tabasco. Carretera Villahermosa-Teapa Km. 25, R/A La Huasteca 2a Sección, CP.86280, Villahermosa, Tabasco, México. Tel: (993) 3581585, 1429151, Fax: (993) 1429150. E-mail: jorge.peralta@ujat.mx
} 
estrus and ovulation in synchronization programs is the application of valerate, cypionate or benzoate estradiol (Melo et al., 2016; Silva et al., 2018).

In this regard, Sales et al. (2012) report that EB and EC have different pharmacokinetic structures. The EC is the result of the esterification of estradiol by the propionic cyclopentane acid, which results in a low solubility in water and the consequent slower release of the administration site and a longer biological activity in comparison with EB (Vynckier et al., 1990), which acts faster than the EC. For this reason, the EC should be administered at the withdrawal of the progestogen and the EB must be administered $24 \mathrm{~h}$ after the withdrawal of the DIB, which requires an additional management for the animals, aspect that can stress the heifers and reduce the rate of pregnancy.

These hormones (EC and EB) have the function of regulating the follicular and luteal phases (Bó et al., 2016), and when the intravaginal device is removed, they have the function of standardizing and reducing the time of ovulation (Peralta-Torres et al., 2010; Sales et al., 2012), thus improving the pregnancy rate (Bó et al., 2013).

Information on the effects of RTD and hormonal treatment on estrous synchronization in zebu heifers under tropical conditions is scarce (Holm et al., 2016). Therefore, the objective of the present study was to determine the effect of RTD (mature and immature) and hormonal treatment (EC and $\mathrm{EB}$ ) on estrous expression rate and pregnancy rate in Bos indicus heifers under tropical conditions. Our hypothesis was that Bos indicus heifers with reproductive tract mature would have higher pregnancy rate. A secondary hypothesis was that heifers received EC upon withdrawal from the intravaginal device are less stressed, which results in a higher pregnancy rate.

\section{MATERIAL AND METHODS}

The experiment was carried out in a ranch located in Tabasco, Mexico, between $17^{\circ} 59^{\prime} \mathrm{N}$ and $92^{\circ} 56^{\prime} \mathrm{W}$ at an altitude of $20 \mathrm{~m}$. The climate of the region is humid tropical with an average temperature of $28.7^{\circ} \mathrm{C}$ and an annual rainfall of $1,940.6 \mathrm{~mm}$ (INEGI, 2014).

Two hundred Brahman (Bos indicus) heifers with $30.5 \pm 1.23$ months of age, body weight of $353.4 \pm 10.0 \mathrm{~kg}$, and body condition score of $4.65 \pm 0.07$ (Ayala et al., 1995) were considered. The heifers were kept, all day, in paddocks of Star grass (Cynodon plectostachyus) and given $1 \mathrm{~kg}$ of commercial feed/animal/day. The feed contained $14 \%$ crude protein. All study procedures were conducted according to the Mexican Official Standard
NOM-062-ZOO-1999 for the production, care, and use of experimental animals.

At the start of the study (day 0), the RTD of the heifers was evaluated using a real-time ultrasound (Emperor ${ }^{\circledR}-830$ Vet, with a $6.5 \mathrm{MHz}$ linear transductor). The heifers were classified into two groups (mature and immature; Fig. 1), criteria for classifying the RTD of Bos indicus heifers were adapted from Anderson et al. (1991) and Cutaia et al. (2006), as described in Table 1.

Thereafter, an intravaginal device $\left(\mathrm{DIB}^{\circledR}\right.$ Lab. Syntex, Argentina) containing $1 \mathrm{~g}$ of progesterone was inserted into each heifer, and $2 \mathrm{mg}$ of estradiol benzoate (EB; Lab. Syntex, Argentina) and $250 \mu \mathrm{g}$ of cloprostenol $\left(\mathrm{PGF}_{2 \alpha}\right.$; Ciclase $^{\circledR}$, Lab. Syntex, Argentina) were intramuscular administered (Fig. 2). Seven days post-insertion, the DIBs were removed, and $250 \mu \mathrm{g} \mathrm{PGF}_{2 \alpha}$ was applied. Heifers with mature $(\mathrm{n}=99)$ or immature reproductive tracts $(\mathrm{n}=101)$ were further divided into two groups. The first group of heifers received $0.5 \mathrm{mg}$ of estradiol cypionate (EC group; Lab. Syntex, Argentina) on the same day 7, and the second group received $1 \mathrm{mg}$ of $\mathrm{EB}$ (EB group) $24 \mathrm{~h}$ later on day 8 (Peralta-Torres et al., 2010b and Butler et al., 2012; Fig. 2).

Twenty-four hours after removal of the DIBs, estrus was detected by visual observation over $60 \mathrm{~h}$ during 1 -h intervals three times a day $(06: 00,12: 00$, and 18:00 h). Fixed-time artificial insemination (FTAI) was carried out $52-56 \mathrm{~h}$ after the removal of the intravaginal device using frozen-thawed semen (Torres-Júnior et al., 2014).

Fifteen days after FTAI, proven bulls were introduced to heifers (1:30 ratio) for $30 \mathrm{~d}$ to determine the effect of reproductive synchronization on pregnancy. The pregnancy diagnosis was carried out using real-time ultrasound scanning. To establish differences between the pregnancy rate after FTAI and natural mating $(\mathrm{NM})$, a first diagnosis was made $45 \mathrm{~d}$ after FTAI and a second $45 \mathrm{~d}$ after bull removal (day 90).

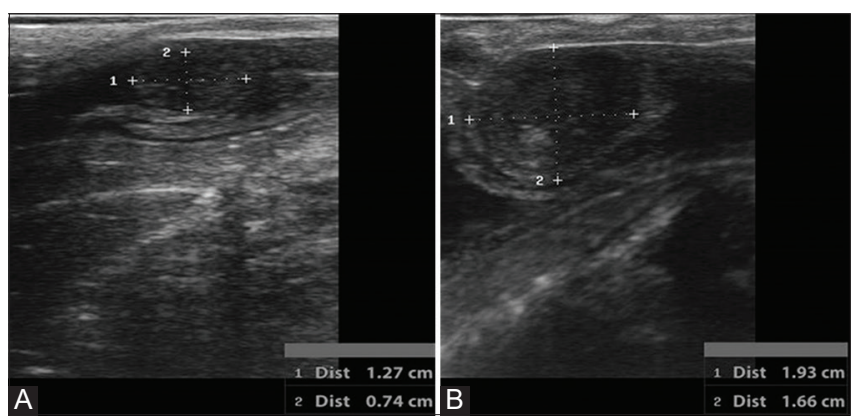

Fig 1. Reproductive tract development in Bos indicus heifers. (A) Immature. (B) Mature. 
Table 1: Criteria for classifying reproductive tracts development of Bos indicus heifers

\begin{tabular}{lcll} 
Reproductive tract & & \multicolumn{2}{c}{ Uterus } \\
\cline { 3 - 4 } development & Diameter of the horn* $(\mathrm{mm})$ & At the moment of palpation & Ovary structure $(\mathrm{mm})$ \\
\hline Immature & $\leq 12.9$ & Without or with light tone & Follicle $<10$ \\
Mature & $\geq 13$ & With tone & Follicles $>10$ and presence of corpus luteum \\
\hline
\end{tabular}

* Cross-sectional measurement of the uterine horn, cranial to bifurcation

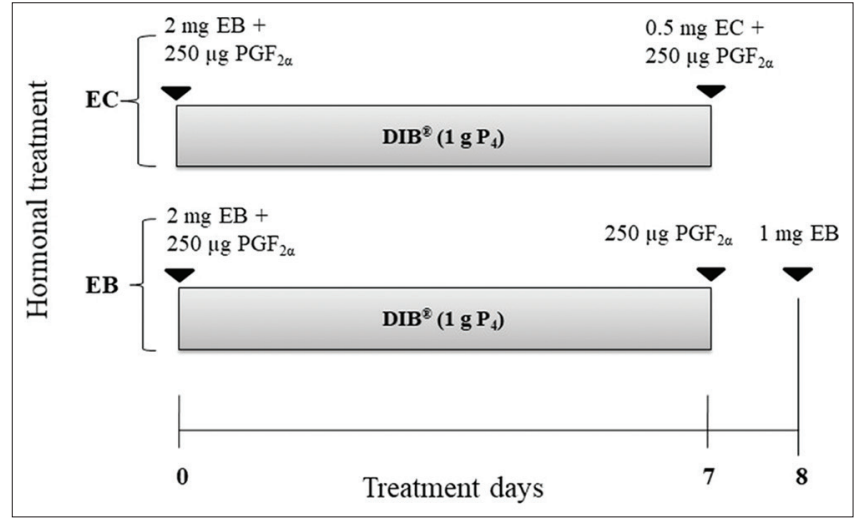

Fig 2. Synchronization program used in Bos indicus heifers with mature or immature reproductive tract. The following abbreviations were used: EC (estradiol cypionate), EB (estradiol benzoate), PGF $_{2 \alpha}$ (prostaglandin $\mathrm{F}_{2 \alpha}$; cloprostenol), DIB ${ }^{\circledR}$ (intravaginal device), $\mathrm{P}_{4}$ (progesterone).

The data of estrous presence $(1=$ Yes, $0=$ Not $)$, pregnancy status after FTAI $(1=$ Yes, $0=$ Not $)$, pregnancy status by NM $(1=$ Yes, $0=$ Not $)$ and total pregnancy $($ FTAI+NM) were subject to logistic regression analysis. Time data, from removal of the intravaginal device to estrus detection, was determined using general linear model analysis. Preliminary analysis of response variables included the fixed effects of RTD (mature or immature), hormonal treatment (EC or $\mathrm{EB})$, and their interaction. However, interactions were not significant and were dropped from the final model.

Data on reproductive traits were described by a fixed binary logistic regression model:

$$
\ln (\mathrm{p} /(1-\mathrm{p}))=\mathrm{b}_{0}+\mathrm{b}_{1} * \mathrm{RTDi}+\mathrm{b}_{2} * \mathrm{HT} \mathrm{j}
$$

where: $\ln =$ natural logarithm; $\mathrm{p}=$ probability of the presence of estrous or pregnancy for a given heifer; $b_{0}=$ intercept; $\mathrm{b}_{1}$ and $\mathrm{b}_{2}=$ regression coefficients; RTD $=$ immature or mature reproductive tract; $\mathrm{HT}=$ hormone treatment using $\mathrm{EC}$ or EB.

For the variable, time from removal of the intravaginal device to estrous detection, the fixed model was:

$$
\mathrm{Y}_{\mathrm{ijk}}=\mu+\mathrm{RTDi}+\mathrm{HTj}_{\mathrm{j}} \mathrm{e}_{\mathrm{ijk}}
$$

where $Y_{\mathrm{ijk}}=$ time from removal to estrous detection associated to the $\mathrm{k}$-th heifer; $\mu=$ mean of all observations; RTD $=$ effect of the $i$-th RTD; HT = effect of the $j$-th hormonal treatment; and $\mathrm{e}_{\mathrm{ij \textrm {k }}}=$ random residual effect.

All statistical analysis were carried out using the logistic and GLM procedures of SAS (SAS, 2009). The significance level was set at $5 \%$.

\section{RESULTS}

The percentage of heifers in estrus and time from removal of the intravaginal device to estrus, was similar between mature and immature heifers $(\mathrm{P}>0.05$; Table 2$)$. Hormonal treatment had only effect on the percentage of heifers in estrus. Heifers treated with EB were 2.65 times more likely to present estrus compared to the group treated with EC (84.3\% vs. $67.3 \% ; \mathrm{P}<0.05)$. However, the pregnancy rate after FTAI $(74.8 \%)$ and total pregnancy $(91.9 \%)$ were higher in the heifers with a mature reproductive tract $(\mathrm{P}<0.05)$. The pregnancy rate by $\mathrm{NM}$ was similar between mature and immature heifers $(\mathrm{P}>0.05$; Table 2$)$.

\section{DISCUSSION}

The percentage of heifers in estrus in the EB group was $17 \%$ higher than the EC group. This finding agree with Uslenghi et al. (2014), who reported a $20 \%$ increase in estrus in heifers treated with EB compared to heifers treated with EC. However, the results of the present study contrast those of Peralta-Torres et al. (2010b), who did not find differences between hormonal treatments $(\mathrm{P}>0.05)$. The greater proportion of heifers found for EB could be due its pharmacokinetic properties, because it is more rapidly absorbed and had a shorter time of action than EC hormone (Vynckier et al., 1990).

The overall mean time interval between intravaginal device removal and the beginning of estrus $(42.6 \mathrm{~h}$ ) was similar to the range $(42-45 \mathrm{~h})$ reported by Peralta-Torres et al. (2010b) but was smaller than the mean $(49.3 \mathrm{~h})$ reported by Colazo et al. (2003). Time from intravaginal device removal to estrus is important for establishing the best moment for FTAI (Ayres et al., 2008; Kasimanickam et al., 2015). Ovulation occurs 30 and $31 \mathrm{~h}$ after cows estrous manifestation when EC or EB is used (Peralta-Torres et al., 2010a). Therefore, when more prolonged is the beginning of estrous, after DIB withdrawal, the time for AI will be misaligned.

The pregnancy rate after FTAI was highest for heifers with a mature RTD, which is in agreement with Holm et al. (2009) results. These latter authors reported a higher pregnancy rate after FTAI in heifers with a mature reproductive tract (grades 5 and 4 with $80 \%$ and $70 \%$, respectability) compared to heifers with an immature 
Table 2: Means $( \pm$ SE) by reproductive tract development and hormonal treatment for percentage of heifers in estrous, time from removal of intravaginal device to estrous, pregnancy rate after FTAI, pregnancy rate by NM and pregnancy rate after FTAI+NM in Bos indicus synchronized heifers

\begin{tabular}{lccccc} 
Items & \multicolumn{2}{c}{ Reproductive tract development } & & \multicolumn{2}{c}{ Hormonal treatment } \\
\cline { 2 - 3 } \cline { 5 - 6 } & Immature & Mature & & Estradiol cypionate & Estradiol benzoate \\
\hline Heifers $(\mathrm{n})$ & 101 & 99 & 98 & 102 \\
Heifers in estrous (\%) & $71.3^{\mathrm{a}}$ & $80.8^{\mathrm{a}}$ & & $67.4^{\mathrm{a}}$ & $84.3^{\mathrm{b}}$ \\
Time from intravaginal device removal to estrous (h) & $43.0^{\mathrm{a}} \pm 0.75$ & $42.3 \mathrm{a} \pm 0.71$ & & $43.0 \mathrm{a} \pm 0.78$ & $42.2 \mathrm{a} \pm 0.67$ \\
Pregnancy after FTAI (\%) & $61.4^{\mathrm{a}}$ & $74.8^{\mathrm{b}}$ & & $71.4^{\mathrm{a}}$ & $64.7^{\mathrm{a}}$ \\
Pregnancy by NM (\%) & $18.8^{\mathrm{a}}$ & $17.1^{\mathrm{a}}$ & & $13.3^{\mathrm{a}}$ & $22.6^{\mathrm{a}}$ \\
Pregnancy after FTAl+NM (\%) & $80.2^{\mathrm{a}}$ & $91.9^{\mathrm{b}}$ & & $84.7^{\mathrm{a}}$ & $87.3^{\mathrm{a}}$ \\
\hline
\end{tabular}

FTAl: fixed time artificial insemination; NM: natural mating. ${ }^{\text {ab }}$ Different literals between columns indicate statistical differences $(\mathrm{P}<0.05)$

reproductive tract (grades 3, 2, and 1 with $53 \%, 40 \%$, and $31 \%$, respectability) $(\mathrm{P}<0.05)$. Kasimanickam et al. (2015) also reported an increased pregnancy rate in heifers with more mature RTD. However, Cutaia et al. (2006), Stevenson et al. (2008), and Butler et al. (2011) did not find an association $(\mathrm{P}>0.05)$ between stage of uterus development and pregnancy rate in heifers. The higher gestation rate of heifers with mature reproductive tract cpuld be related to a better development of the reproductive tract, as well as to the production of estradiol during the pre-ovulatory period (Claro et al., 2010; Souza et al., 2011). Estradiol causes proliferative changes in the uterine tissues, which are reflected in the growth and development of luminal and glandular epithelial cells, and the secretion of luminal proteins (Johnson et al., 1997).

No differences in pregnancy rate $(\mathrm{P}>0.05)$ were found between the $\mathrm{EC}$ and $\mathrm{EB}$ groups, which agrees with the results of Meneghetti et al. (2009) for Nellore cattle (50.8\% and $51.9 \%$ pregnancy rate, respectively) and Uslenghi et al. (2016) for Bos taurus beef cows ( $54 \%$ and $49.2 \%$ pregnancy rate, respectively). However, Uslenghi et al. (2014) reports the effects of hormonal treatment on pregnancy rate, founding a higher rate after EB (61.5\%) compared to EC treatment (48.9\%). The results found in the present study indicate that the type of estrogen used does not influence the gestation rate; however, the advantage of $\mathrm{EC}$ is to reduce the management of heifers in programs using FTAI.

For the NM group, no differences were found in pregnancy rate ( $\mathrm{P}>0.05)$, which agrees with Butler et al. (2011), who did not find any association between the stage of uterus development and pregnancy in naturally mated heifers. This result could address the ability of the treatment to induce of return to estrus in heifers that did not become pregnant at first insemination (Butler et al., 2011).

The total pregnancy rate (FTAI + NM) was greater for heifers with a mature reproductive tract $(92 \%)$, which disagrees with Butler et al. (2011), who reported no differences in pregnancy rate for heifers with different RTD.
The overall pregnancy rate found herein is similar to that reported by Gottschall et al. (2012), who reported $91.7 \%$ gestating females $100 \mathrm{~d}$ after beginning the study. Baruselli et al. (2004) and Salgado et al. (2009) found pregnancy rates of $79 \%$ at $90 \mathrm{~d}$ and $70.4 \%$ at $60 \mathrm{~d}$, respectively.

Total pregnancy rate in the present study is also higher than the value $(80.7 \%)$ obtained by Bó et al. (2007). In addition, Gutierrez et al. (2014) reported that heifers with more developed reproductive tracts had higher pregnancy rates than heifers with immature reproductive tracts.

\section{CONCLUSIONS}

Under the conditions of this study, Bos indicus heifers with mature reproductive tracts had higher pregnancy rate under fixed-time artificial insemination and higher total pregnancy than immature heifers.

Hormone treatment did not influence pregnancy rate; therefore, it is possible to use estradiol cypionate to reduce heifer handling.

\section{ACKNOWLEDGEMENTS}

To the "Programa de Fomento a la Investigación y Consolidación de los Cuerpos Académicos (PFICA; Clave: UJAT-2010-C06-04) de la Universidad Juárez Autónoma de Tabasco (UJAT)" by the financial grunt. To the Bustamante León family for providing the animals used in this study.

\section{AUTHORS' CONTRIBUTIONS}

All the authors wrote, read and approved the manuscript. Jorge Alonso Peralta-Torres, Oswaldo Margarito TorresChablé, Nadia Florencia Ojeda-Robertos carried out the experiment, designed the research plan and organized the study. Carlos Luna-Palomera, Jesús Ricardo Aké-López and José Candelario Segura-Correa conducted the statistical analysis and interpretation of data. 


\section{REFERENCES}

Anderson, K. J., D. G. LeFever, J. S. Brinks and K. G. Odde. 1991. The use of reproductive tract scoring in beef heifers. Agri. Practice. 12: 19-26.

Ayala, A., R. Delgado, N. Honhold and J. Magaña. 1995. A visual condition scoring scheme for Bos indicus and crossbred cattle. In: Anderson, S. and J. Wadsworth, (Eds.), Dual Purpose Cattle Production Research. International Foundation for Science, FMVZ-UADY, México, pp. 119-128.

Ayres, H., C. M. Martins, R. M. Ferreira, J. E. Mello, J. H. Dominguez, A. H. Souza, R. Valentin, I. C. Santos and P. S. Baruselli. 2008. Effect of timing of estradiol benzoate administration upon synchronization of ovulation in suckling Nelore cows (Bos indicus) treated with a progesterone-releasing intravaginal device. Anim. Reprod. Sci. 109: 77-87.

Baez, G. M., R. V. Barletta, J. N. Guenther, J. M. Gaska and M. C. Wiltbank. 2016. Effect of uterine size on fertility of lactating dairy cows. Theriogenology. 85: 1357-1366.

Barcellos, J. O., G. R. Pereira, E. A. Dias, C. McManus, L. Canellas, M. L. Bernardi, A. Tarouco and E. R. Prates. 2014. Higher feeding diets effects on age and live weight gain at puberty in crossbred Nelore-Hereford heifers. Trop. Anim. Health Prod. 46: 953-960.

Baruselli, P. S., E. L. Reis, M. O. Marques, L. F. Nasser and G. A. Bó. 2004. The use of hormonal treatments to improve reproductive performance of anestrous beef cattle in tropical climates. Anim. Reprod. Sci. 82-83: 479-486.

Bó, G. A. and P. S. Baruselli. 2014. Synchronization of ovulation and fixed-time artificial insemination in beef cattle. Animal. 8: 144-150.

Bó, G. A., J. J. de la Mata, P. S. Baruselli and A. Menchaca. 2016. Alternative programs for synchronizing and resynchronizing ovulation in beef cattle. Theriogenology. 86: 388-396.

Bó, G. A., L. Cutaia, L. C. Peres, D. Pincinato, D. Maraña and P. S. Baruselli. 2007. Technologies for fixed-time artificial insemination and their influence on reproductive performance of Bos indicus cattle. Soc. Reprod. Fertil. Suppl. 64: 223-236.

Bó, G. A., P. S. Baruselli and R. J. Mapletoft. 2013. Synchronization techniques to increase the utilization of artificial insemination in beef and dairy cattle. Anim. Reprod. 10: 137-142.

Bruinjé, T. C., Rosadiuk, J. P., F. Moslemipur, J. E. Carrelli, M. A. Steele and D. J. Ambrose. 2019. Carryover effects of pre- and postweaning planes of nutrition on reproductive tract development and estrous cycle characteristics in Holstein heifers. J. Dairy Sci. 102: 10514-10529.

Butler, S. A., N. L. Phillips, G. B. Boe-Hansen, G. A. Bó, B. M. Burns, K. Dawson and M. R. McGowan. 2012. Animal-Level Factors Affecting Ovarian Function in Bos indicus Heifers Treated to Synchronize Ovulation with Intravaginal ProgesteroneReleasing Devices and Oestradiol Benzoate. Reprod. Domest. Anim. 47: 463-471.

Butler, S. A., P. C. Atkinson, G. B. Boe-Hansen, B. M. Burns, K. Dawson, G. A. Bó and M. R. McGowan. 2011. Pregnancy rates after fixed-time artificial insemination of Brahman heifers treated to synchronize ovulation with low-dose intravaginal progesterone releasing devices, with or without eCG. Theriogenology. 76: 1416-1423.

Claro I. Jr., O. G. Sá Filho, R. F. Peres, F. H. Aono, M. L. Day and J. L. Vasconcelos. 2010. Reproductive performance of prepubertal Bos indicus heifers after progesterone-based treatments. Theriogenology. 74: 903-911.

Colazo, M. G., J. P. Kastelic and R. J. Mapletoft. 2003. Effects of estradiol cypionate (ECP) on ovarian follicular dynamics, synchrony of ovulation, and fertility in CIDR-based, fixed-time AI programs in beef heifers. Theriogenology. 60: 855-865.

Cutaia, L., L. Peres, D. Pincinato and G. A. Bó. 2006. Influence of uterine diameter, ovarian size and ovarian structures on fertility in 15 months old cross-bred Bonsmara heifers inseminated at Fixed-Time. Acta Sci. Vet. 34: 387.

Dickinson, S. E., M. F. Elmore, L. Kriese-Anderson, J. B. Elmore, B. N. Walker, P. W. Dyce, S. P. Rodning and F. H. Biase. 2019. Evaluation of age, weaning weight, body condition score, and reproductive tract score in pre-selected beef heifers relative to reproductive potential. J. Anim. Sci. Biotechnol. 10: 18.

Gottschall, C. S., M. R. Almeida, F. Tolotti, J. Magero, H. R. Bittencourt, R. C. Mattos and R. M. Gregory. 2012. Avaliação do desempenho reprodutivo de vacas de corte lactantes submetidas à IATF a partir da aplicação do $\mathrm{GnRH}$, da manifestação estral, da reutilização de dispositivos intravaginais e da condição corporal. Acta Sci. Vet. 40: 1012.

Gutierrez, K., R. Kasimanickam, A. Tibary, J. M. Gay, J. P. Kastelic, J. B. Hall and W. D. Whittier. 2014. Effect of reproductive tract scoring on reproductive efficiency in beef heifers bred by timed insemination and natural service versus only natural service. Theriogenology. 81: 918-924.

Holm, D. E., M. Nielen, R. Jorritsma, P. C. Irons and P. N. Thompson. 2016. Ultrasonographic reproductive tract measures and pelvis measures as predictors of pregnancy failure and anestrus in restricted bred beef heifers. Theriogenology. 85: 495-501.

Holm, D. E., M. Nielen, R. Jorritsma, P. C. Irons and P. N. Thompson. 2015. Evaluation of pre-breeding reproductive tract scoring as a predictor of long term reproductive performance in beef heifers. Prev. Vet. Med. 118: 56-63.

Holm, D. E., P. N. Thompson and P. C. Irons. 2009. The value of reproductive tract scoring as a predictor of fertility and production outcomes in beef heifers. J. Anim. Sci. 87: 1934-1940.

INEGI. 2014. Instituto Nacional de Estadística y Geografía. Perspectiva Estadística. Tabasco. Available from: http://internet. contenidos.inegi.org.mx/contenidos/productos/prod_serv/ contenidos/espanol/bvinegi/productos/integracion/estd_ perspect/sep_20145/tab/702825067830.pdf. [Last accessed on 2018 May 25].

Johnson, M. L., D. A. Redmer and L. P. Reynolds. 1997. Effects of ovarian steroids on uterine growth, morphology, and cell proliferation in ovariectomized, steroid-treated ewes. Biol. Reprod. 57: 588-596.

Kasimanickam, R. K., J. B. Hall and W. D. Whittier. 2017. Fertility of Angus cross beef heifers after $\mathrm{GnRH}$ treatment on day 23 and timing of insemination in 14- day CIDR protocol. Reprod. Domest. Anim. 52: 122-129.

Kasimanickam, R. K., V. R. Kasimanickam, J. Oldham and M. Whitmore. 2020. Cyclicity, estrus expression and pregnancy rates in beef heifers with different reproductive tract scores following progesterone supplementation. Theriogenology. 145: 39-47.

Kasimanickam, R. K., W. D. Whittier, J. B. Hall and J. P. Kastelic. 2016. Estrous synchronization strategies to optimize beef heifer reproductive performance after reproductive tract scoring. Theriogenology. 86: 831-838.

Kasimanickam, R., S. Schroeder, J. B. Hall and W. D. Whittier. 2015. Fertility after implementation of long- and short-term progesterone-based ovulation synchronization protocols for fixed-time artificial insemination in beef heifers. Theriogenology. 83: 1226-1232.

Lardner, H. A., D. Damiran, S. Hendrick, K. Larson and R. Funston. 2014. Effect of development system on growth and reproductive performance of beef heifers. J. Anim. Sci. 92: 3116-3126. 
Melo, L. F., P. L. J. Jr. Monteiro, R. S. Surjus, J. N. Drum, M. C. Wiltbank and R. Sartori. 2016. Progesterone-based fixed-time artificial insemination protocols for dairy cows: Gonadotropin-releasing hormone versus estradiol benzoate at initiation and estradiol cypionate versus estradiol benzoate at the end. J. Dairy Sci. 99: 9227-9237.

Meneghetti, M., O. G. Sá Filho, R. F. Peres, G. C. Lamb and J. L. Vasconcelos. 2009. Fixed-time artificial insemination with estradiol and progesterone for Bos indicus cows: I. Basis for development of protocols. Theriogenology. 72: 179-189.

Monteiro, F. M., M. E. Z. Mercadante, C. M. Barros, R. A. Satrapa, J. A. V. Silva, L. Z. Oliveira, N. Z. Saraiva, C. S. Oliveira and J. M. Garcia. 2013. Reproductive tract development and puberty in two lines of Nellore heifers selected for postweaning weight. Theriogenology. 80: 10-17.

Peralta-Torres J., J. Aké-López, F. Centurión-Castro and J. MagañaMonforte. 2010a. Comparison of estradiol cypionate and estradiol benzoate effects on ovaric activity, estrus and ovulation on anestrus Bos indicus cows. J. Anim. Vet. Adv. 9: 466-470.

Peralta-Torres, J. A., J. R. Aké-López, F. G. Centurión-Castro and J. G. Magaña-Monforte. 2010b. Comparación del cipionato de estradiol vs benzoato de estradiol sobre la respuesta a estro y tasa de gestación en protocolos de sincronización con CIDR en novilla y vacas Bos indicus. Universidad y Ciencia. 26: 163-169.

Sales, J. N. S., J. B. P. Carvalho, G. A. Crepaldi, R. S. Cipriano, J. O. Jacomini, J. R. G. Maio, J. C. Souza, G. P. Nogueira and P. S. Baruselli. 2012. Effects of two estradiol esters (benzoate and cypionate) on the induction of synchronized ovulations in Bos indicus cows submitted to a timed artificial insemination protocol. Theriogenology. 78: 510-516.

Salgado, R. O., O. G. Vergara and J. S. Simanca. 2009. Eficiencia reproductiva en ganado Bos indicus mediante la utilización de programas de inseminación artificial a tiempo fijo. Livestock Res. Rural Dev. 21: 134.

SAS. 2009. Statistical Analysis Systems Package. Version 9.2. SAS ${ }^{\circledR}$ Institute, Inc., Cary, NC. United State.

Silva, E. P., M. C. Wiltbank, A. B. Machado, L. S. Gambin, M. M. Dias, M. F. C. Chaiben, M. L. Bernardi and J. B. S. Borges. 2018.
Optimizing timed Al protocols for Angus beef heifers: Comparison of induction of synchronized ovulation with estradiol cypionate or $\mathrm{GnRH}$. Theriogenology. 121: 7-12.

Souza, A. H., E. P. B. Silva, A. P. Cunha, A. Gümen, H. Ayres, D. J. Brusveen, J. N. Guenther and M. C. Wiltbank. 2011. Ultrasonographic evaluation of endometrial thickness near timed $\mathrm{Al}$ as a predictor of fertility in high-producing dairy cows. Theriogenology. 75: 722-733.

Stevenson, J. L., J. A. Rodrigues, F. A. Braga, S. Bitente, J. C. Dalton, J. E. Santos and R. C. Chebel. 2008. Effect of breeding protocols and reproductive tract score on reproductive performance of dairy heifers and economic outcome of breeding programs. J. Dairy Sci. 91: 3424-3438.

Torres-Júnior, J. R. S., L. Penteado, J. N. S. Sales, M. F. Sá Filho, H. Ayres and P. S. Baruselli. 2014. A comparison of two different esters of estradiol for the induction of ovulation in an estradiol plus progestin-based timed artificial insemination protocol for suckled Bos indicus beef cows. Anim. Reprod. Sci. 151: 9-14.

Uslenghi, G., A. Vater, S. Rodríguez Aguilar, J. Cabodevila and S. Callejas. 2016. Effect of estradiol cypionate and $\mathrm{GnRH}$ treatment on plasma estradiol-17ß concentrations, synchronization of ovulation and on pregnancy rates in suckled beef cows treated with FTAI-based protocols. Reprod. Domest Anim. 51: 693-699.

Uslenghi, G., S. G. Chaves, J. Cabodevila and S. Callejas. 2014. Effect of estradiol cypionate and amount of progesterone in the intravaginal device on synchronization of estrus, ovulation and on pregnancy rate in beef cows treated with FTAl based protocols. Anim. Reprod. Sci. 145: 1-7.

Vynckier, L., M. Debackere, A. De Kruif and M. Coryn. 1990. Plasma estradiol-17 beta concentrations in the cow during induced estrus and after injection of estradiol- 17 beta benzoate and estradiol-17 beta cypionate - a preliminary study. J. Vet. Pharmacol. Ther. 13: 36-42.

Young, C., F. A. Di Croce, D. Roper, J. Harris, N. Rohrbach, J. Wilkerson and F. N. Schrick. 2011. Effect of reproductive tract size on conception rates in lactating dairy cows utilizing a reproductive tract scoring system. Reprod. Fertil. Dev. 23: 119. 